\title{
Isolation of 2'-Deoxy-2'-Azidocytidine-Resistant Mutants Deficient in Deoxycytidine Kinase in Mouse FM3A Cells
}

\author{
Kimiko Iwata, Dai Ayusawa and Takeshi Seno \\ Department of Immunology and Virology, Saitama Cancer Center Research \\ Institute, Ina-machi, Saitama 362, Japan
}

\begin{abstract}
We isolated several mutants that are highly resistant to $2^{\prime}$ deoxy-2'-azidocytidine by culturing mutagenized mouse FM3A cells in a medium containing $10^{-4} \mathrm{M}$ of this analogue. The mutants incorporated deoxycytidine into acid-insoluble materials at a reduced rate, but incorporated cytidine normally. All the mutants isolated also were resistant to $1-\beta$-D-arabinofuranosylcytosine. The activity of deoxycytidine kinase in the crude extracts of these mutants was reduced to about $10 \%$ that of the FM3A cells. Our results indicate that $2^{\prime}$-deoxy- $2^{\prime}$-azidocytidine is recognized as deoxyribonucleoside by deoxycytidine kinase in contrast to reports that phosphate forms of this nucleoside analogue are recognized as ribonucleotide by the ribonucleotide reductase from calf thymus and $E$. coli and by $E$. coli primase.
\end{abstract}

A nucleoside analogue, $2^{\prime}$-deoxy-2'-azidocytidine $(\mathrm{Cz}$, or azidocytidine)* inhibits the growth of cultured mammalian cells by interfering with DNA replication (9). Isolation and characterization of mutants resistant to $\mathrm{Cz}$ in mammalian cells should be of great value for the study of inhibitory mechanisms in vivo. Resistance to any nucleoside analogue can be produced by more than one mechanisms. Among the Cz-resistant mutants isolated in our laboratory, we found some that were stable and highly resistant to $\mathrm{Cz}$. We here report the characterization of these mutants.

A subclone, F28-7, isolated from FM3A cells (7), was used as a wild type cell line in this study. Cells were grown in a floating culture at $37^{\circ} \mathrm{C}$ in Eagle's minimum essential medium supplemented with $2 \%$ fetal calf serum and $0.1 \%$ Bactopeptone as described previously (1). Cells were mutagenized with $0.6 \mu \mathrm{g} / \mathrm{ml}$ of $\mathrm{N}$-methyl-N'-nitro$\mathrm{N}$-nitrosoguanidine (Sigma Co.) for $3 \mathrm{~h}$ then cultured for 2 days to stabilize mutated phenotypes. These cells then were cultured for 10 days in a medium containing $5 \times$ $10^{-4} \mathrm{M} \mathrm{Cz}$ (Boehringer, Mannheim $\mathrm{GmbH}$ ), after which they were transferred to fresh medium containing $1 \times 10^{-3} \mathrm{M} \mathrm{Cz}$ and cultured for another week. Cells that grew under this selection condition were cloned on agar medium $(0.5 \%$ agar $)$. Fig. 1 shows the growth in the presence or absence of $\mathrm{Cz}$ of the wild type FM3A and its two Cz-resistant mutants (FScz2 and FScz3) as representatives of ten mutant clones isolated. From the concentration of $\mathrm{Cz}$ that reduced the growth rate of cells to $50 \%$, we judged the two resistant clones to be about 100-times more resistant to $\mathrm{Cz}$ than the wild type FM3A. This phenotype has been stable for over a year.

* Abbreviations: $\mathrm{Cz}$ and azidocytidine, 2'-deoxy-2'-azidocytidine; CzDP, 5'-diphosphate of $\mathrm{Cz}$; CzTP, 5'-triphosphate of $\mathrm{Cz}$; araC, 1- $\beta$-D-arabinofuranosylcytosine. 


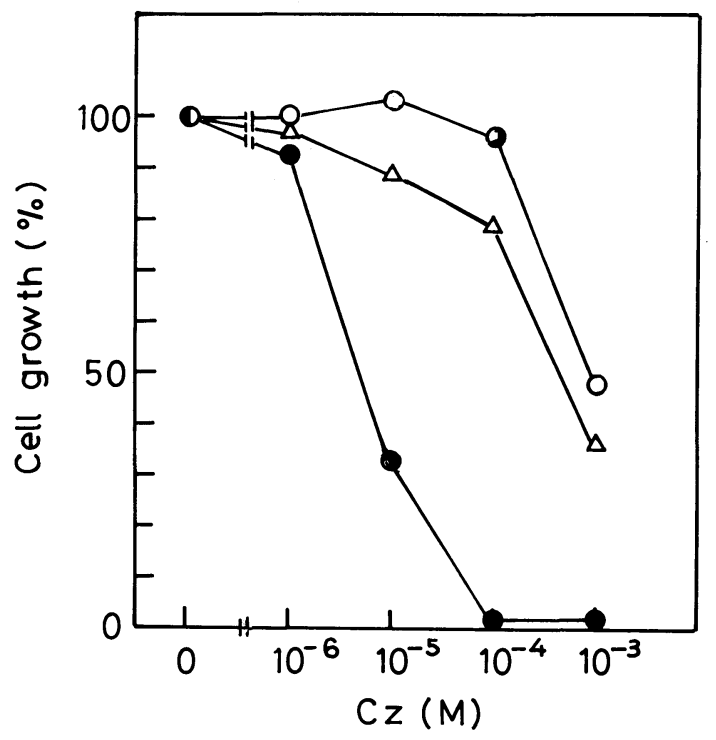

Fig. 1. Effect of azidocytidine on the growth of wild type FM3A and the mutant FScz2 and FS $c z 3$ cells. Cells were inoculated at a density of $1 \times 10^{5}$ cells $/ \mathrm{ml}$. After three days of culture, viable cells were counted. $\bullet$, FM3A cells; $\bigcirc, \mathrm{FS} c z 2$ cells; $\triangle$, FScz3 cells.

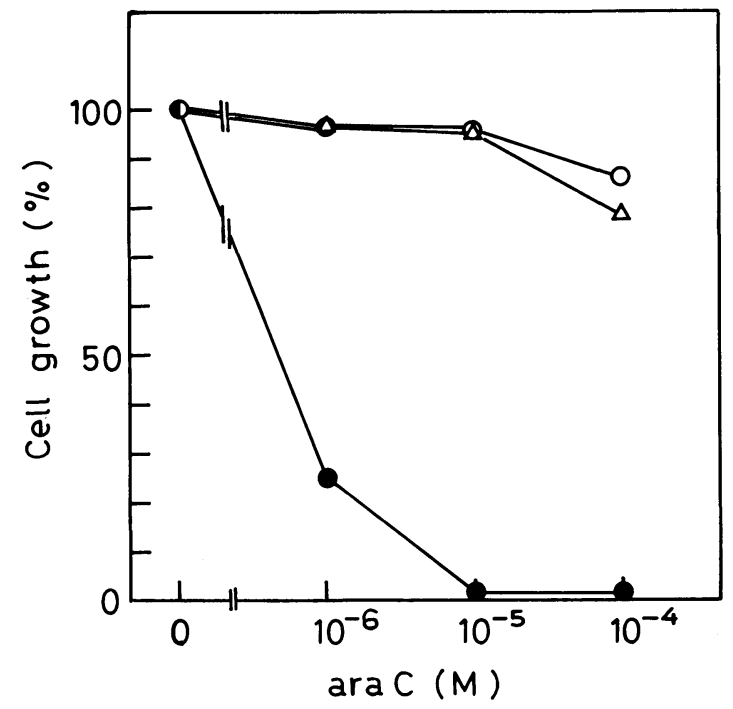

Fig. 2. Effect of 1- $\beta$-D-arabinofuranosylcytosine on the growth of wild type FM3A and the mutant FS $c z 2$ and FS $c z 3$ cells. Growth was determined as described in the legend to Fig. 1. ๑, FM3A cells; $\bigcirc, \mathrm{FS} c z 2$ cells; $\triangle$, FScz3 cells. 
To check for any alterations in the transport or phosphorylating steps of the nucleosides or in the polymerases in the mutants, we measured the ability of the cells to incorporate $\left[{ }^{3} \mathrm{H}\right]$ cytidine and $\left[{ }^{3} \mathrm{H}\right]$ deoxycytidine (Radiochemical Centre, Amersham) into an acid-insoluble fraction. The mutants, FS $c z 2$ and FS $c z 3$, both showed reduction in their ability to incorporate $\left[{ }^{3} \mathrm{H}\right]$ deoxycytidine into acid-insoluble macromolecules as compared with wild type FM3A. By contrast, the incorporation of $\left[{ }^{3} \mathrm{H}\right]$ cytidine was normal (data not shown). We then examined the cross resistance to a deoxycytidine analogue, 1- $\beta$-D-arabinofuranosylcytosine (araC), because mutants concerning utilization of deoxycytidine have been reported to undergo alterations in their sensitivity to araC $(3,6)$. The mutants also showed more than a 100 times higher resistance to araC than the wild type FM3A (Fig. 2). These results indicate that the mutants may have defects in the transport of deoxycytidine or alterations either in the metabolic pathway of deoxycytidine or in the DNA polymerizing machinery. Mutants highly resistant to araC are reported to be deficient in deoxycytidine kinase (3). Table 1 shows the activities of deoxycytidine kinase and cytidine kinase of the crude extracts obtained from the two resistant mutants, FScz2 and FScz3. The activity of deoxycytidine kinase in FScz2 and FScz3 cells decreased markedly to $9 \%$ and $14 \%$ of the activity of the FA3M cells, but the activity of cytidine kinase was unaltered in the two mutants. The actual activities of deoxycytidine kinase in the mutants should be much less than those shown in Table 1 because the assay method for deoxycytidine kinase used can not exclude the deoxyuridine monophosphate produced by the action of the pyrimidine nucleoside deaminase and deoxyuridine kinase present in the crude extracts. Thus, there is strong evidence that the resistant phenotype was caused by the defect in deoxycytidine kinase. To determine whether the Cz-resistance is genetically dominant or recessive, the mutant FScz3 cells were hybridized with FS5oua1 cells, which carry a recessive trait of temperature-sensitivity for growth, the dominant trait of resistance to ouabain, as well as the wild type trait of Cz-sensitivity (unpublished). Cell-hybridization was carried out with polyethylene glycol 1540 (Wako Pure Chemical Industries, Japan) as described previously (1). The hybrid cells (FScz3 $\times$ FS5oual) grew at a non-permissive temperature, $39.5^{\circ} \mathrm{C}$, on agar medium containing $2 \mathrm{mM}$ ouabain. The hybrid

TABLE 1. ACTIVITIES OF DEOXYCYTIDINE KINASE AND CYTIDINE KINASE IN WILD TYPE FM3A AND ITS TWO AZIDOCYTIDINE-RESISTANT MUTANTS.

\begin{tabular}{|c|c|c|c|c|}
\hline \multirow{2}{*}{ Cell line } & \multicolumn{2}{|c|}{ Deoxycytidine kinase } & \multicolumn{2}{|c|}{ Cytidine kinase } \\
\hline & Activitya) & $(\%)$ & Activitya) & $(\%)$ \\
\hline FM3A & $0.07^{\mathrm{b})}$ & 100 & $1.41^{\mathrm{b})}$ & 100 \\
\hline $\mathrm{FS} c z 2$ & 0.006 & 9 & 1.59 & 113 \\
\hline $\mathrm{FS} c z 3$ & 0.01 & 14 & 0.93 & 66 \\
\hline
\end{tabular}

Cells were grown in $100 \mathrm{ml}$ of the medium to a density of $1 \times 10^{6}$ cells $/ \mathrm{ml}$. After harvest, the cells were washed once with ice-cold phosphate-buffered saline then disrupted by repeated freezing and thawing ( 3 times), after which they were suspended in $5 \mathrm{ml}$ of a buffer containing $50 \mathrm{mM}$ Tris- $\mathrm{HCl}(\mathrm{pH} \mathrm{7.5}$ ), $1 \mathrm{mM}$ EDTA and $5 \mathrm{mM}$ 2-mercaptoethanol. The supernatant, obtained by centrifugation of the cell homogenate at $105,000 \times \mathrm{g}$ for $90 \mathrm{~min}$, was dialyzed against buffer containing $10 \mathrm{mM}$ Tris- $\mathrm{HCl}(\mathrm{pH}$ 7.5), $1 \mathrm{mM}$ EDTA, $5 \mathrm{mM}$ 2-mercaptoethanol and $50 \%$ (v/v) glycerol, and used for the enzyme assay and to determine the protein content. Assay of the kinases was according to Chu and Fischer (2). Protein was determined by the method of Lowry et al. (5). a) Activity is given as the number of pmoles dCMP or CMP formed per mg protein per $15 \mathrm{~min}$ at $30^{\circ} \mathrm{C}$. b) A separate assay gave similar results. 
clones that were isolated could not grow in the medium containing $10^{-5} \mathrm{M}$ araC, although FScz3 cells grew normally under the same condition (data not shown). Our results show that the araC-resistance is a recessive character. Hence, we concluded that $\mathrm{Cz}$-resistance was produced by the deficiency in deoxycytidine kinase.

The results of this study show that $\mathrm{Cz}$, an analogue of both ribo- and deoxynucleoside (see ref. 8), is recognized by deoxycytidine kinase, but not by cytidine kinase at the step of nucleoside phosphorylation in mouse FM3A cells. CzDP has been reported to be an inhibitor of calf thymus ribonucleotide reductase competitive with CDP (4) and to inactivate $E$. coli ribonucleotide reductase (10). In addition, CzTP is a substrate of primase in E. coli (8). Thus, our present results are evidence that a chemically modified sugar moiety of a nucleoside does not always act strictly as an analogue of ribonucleoside or deoxyribonucleoside in vivo. Thus, a modified sugar moiety of nucleosides other than $\mathrm{Cz}$ also may be recognized as a deoxyribonucleoside analogue by one enzyme and as a ribonucleoside analogue by another in a cell.

Acknowledgments. This work was supported in part by a Grant-in-Aid for Cancer Research from the Ministry of Education, Science and Culture of Japan.

\section{REFERENCES}

1. Ayusawa, D., H. Koyama, K. Iwata and T. Seno. Single-step selection of mouse FM3A cell mutants defective in thymidylate synthetase. Somat. Cell Genet., in press

2. Chu, M. Y. and G. A. Fischer. Comparative studies of leukemic cells sensitive and resistant to cytosine arabinoside. Biochem. Pharmacol. 17, 333-341, 1965

3. Clements, G. B. Selection of biochemically variant, in some cases mutant, mammalian cells in culture. Adv. Cancer Res. 21, 274-380, 1975

4. Engstrom, Y., S. Eriksson, L. Thelander and M. Akerman. Ribonucleotide reductase from calf thymus. Purification and properties. Biochemistry 18, 2941-2948, 1979

5. Lowry, O. H., N. J. Rosenbrough, A. L. Farr and R. J. Randall. Protein measurement with Folin phenol reagent. J. Biol. Chem. 193, 265-275, 1951

6. Momparler, R. L., T. P. Brent, A. Labitan and V. Krygier. Studies on the phosphorylation of cytosine arabinoside in mammalian cells. Molec. Pharmacol. 7, 413-419, 1971

7. NaKano, N. Establishment of cell lines in vitro from a mammary ascites tumor of mouse and biological properties of the established lines in a serum containing medium. Tohoku J. Exp. Med. 88, 69-84, 1966

8. Reichard, P., L. Rowen, R. Eliasson, J. Hobbs and F. Eckstein. Inhibition of primase, the dna $\mathrm{G}$ protein of Escherichia coli by $2^{\prime}$-deoxy-2'-azidocytidine triphosphate. J. Biol. Chem. 253, 7011-7016, 1978

9. Skoog, L., G. Buursell, L. Thelander, T. HÄgerström, J. Hobbs and F. Eckstein. 2'-deoxy2 '-azidocytidine, a new inhibitor of DNA replication in mammalian cells. Eur. J. Biochem. 72 , 371-378, 1977

10. Thelander, L., B. Larsson, J. Hobbs and F. Eckstein. Active site of ribonucleoside diphosphate reductase from Escherichia coli. Inactivation of the enzyme by $2^{\prime}$-substituted ribonucleoside diphosphates. J. Biol. Chem. 251, 1398-1405, 1976

(Received for publication, September 20, 1979) 